\title{
THE READINESS OF ENGLISH COMMUNICATION SKILLS OF MATARAM TOURISM VOCATIONAL COLLEGE STUDENTS FOR ASEAN ECONOMIC COMMUNITY
}

\author{
Ida Nyoman Tri Darma Putra \\ Sekolah Tinggi Pariwisata Mataram \\ Ida.nyoman.putra@gmail.com
}

\begin{abstract}
The purpose of this study was to find out the readiness of English communication skills of tourism students at Mataram Tourism Vocational College to enter the ASEAN Economic Community era. The scope of this study includes students from three tourism study programs, namely diploma 3 programs in hotel and hospitality, diploma 3 tours and travel and bachelor program in tourism. A total of 110 respondents were used in this study. Four English communication skills including listening, speaking, reading, and writing are measured using questionnaires as instruments for collecting data. Statistical analysis includes percentages, averages, and standard deviations. The research findings revealed that Tourism students at STP Mataram need to develop and improve their skills in English communication, especially listening and speaking which is a skill needed to communicate with foreigners, especially in NTB. From the four skills of language, STP Mataram student Language skills are not ready to communicate using English, 30\% respondents answered that they have not been able or disagree from the questionnaire.
\end{abstract}

Keywords: Readiness, English, Communication, Skills

\section{INTRODUCTION}

\section{ASEAN (Association of South East}

Asian Nations) is an organization of Southeast Asian countries. Established on August 8, 1967 in Bangkok through the signing of the ASEAN Declaration (Bangkok Declaration) by five founding countries, namely Indonesia, Malaysia, the Philippines, Singapore, and Thailand. The ASEAN Economic Community (MEA) or the ASEAN Economic Community (AEC) which was initiated in 2015 is a challenge and opportunity including in the field of tourism. The ASEAN Economic Community (MEA) is already underway and Indonesia needs preparation to be ready in the free market of the ASEAN community. Through MEA, domestic entrepreneurs can expand their business network to the international realm. Step by step, the strategy that must be carried out is in accordance with what was recommended in the foundation of the MEA in 2015 which requires that each ASEAN country will reform all elements that become the essential and absolute sectors needed to deal with MEA implementation. According to Joseph Stiglitz (2004), no country can avoid globalization. Establishing relationships and networks in the era of globalization is very important. Economic globalization requires an increase in strong competitiveness in technology, management, human resources and ongoing efforts to encourage innovation and create cost efficiency. Thus, to compete in the preparation of a borderless or unlimited world is to communicate with both written and oral English that can be used in the economic, social, cultural, educational and political sectors.

Readiness of the quality of human resources is the key to success in facing the 
free market in the MEA era. Foreign language skills, especially English, are one of the most important and necessary qualities and the success of this MEA will be influenced by mastery of English. In MEA the use of English will be the dominant communication tool to win global competition in the future. English which is also an international language is naturally understood as a foreign language that will be used to communicate within the community of ASEAN countries.

At present, the working language in ASEAN countries is the use of English as a lingua franca language. Lingua franca is a language used to communicate between people who come from different language backgrounds. Tourism higher education which is an important sector in the MEA has a significant role in English language education. Communities are expected to be able to communicate actively with English, both written and oral in official communication and communicate with others regionally / internationally. Community readiness and students in higher education in mastering English as a means of global communication are very important.

The ASEAN Economic Community (MEA) is an important step for every ASEAN country, especially in the tourism industry (Ushakov, 2014). Employees in this field need to improve their communication skills, especially in English communication, because the tourism industry is the main source of foreign currency. Therefore, human resources need to be improved in order to fully utilize the single market of the MEA (Wongleedee, 2012).

According to the Indonesian Proficiency Index (EPI) research compared to ASEAN countries, it is in third place in
ASEAN (McCormick, 2015). The highest number one EPI is Malaysia and the second is Singapore, followed by Vietnam, Thailand, and Cambodia. Indonesia is in an English-language position with moderate abilities.

This research is important to do considering the readiness of tourism students in NTB to face the rapid development of tourism. In addition, graduate users will tend to use and trust the institutions of higher education that are ready in their foreign language competencies. In addition, the results of this study can be used as a basis for development and planning to what extent the readiness of tourism students, especially those in Mataram Tourism College, West Nusa Tenggara in their competence and readiness to use English as a communication tool.

According to Paul Lewis (2009), that English places the 3rd rank as the most widely used language in countries in the world. English has been used by countries in the ASEAN region. English is the language most widely used by countries in the world. This is a strong reason why Indonesian citizens, especially tourism students, must be able to use English to face the MEA. As the world's lingua franca, English is a global communication tool.

Language besides its function as a tool for communication is also the main tool to get to know the world. With language humans can know about the world and can understand other humans. With the passage of the 2015 MEA, it is an opportunity for ASEAN countries to come to Indonesia. This will cause many foreign workers to work in Indonesia. Therefore, Indonesia must immediately prepare people who are competent and ready for 
this, especially for tourism students. This was also supported by the President of Indonesia; Joko Widodo had signed Presidential Decree No. 69 of 2015 concerning Visa Free Visits for foreign nationals from certain countries. The purpose of this is to increase the number of tourists while increasing travel visas. The consequences of this will automatically enliven the MEA and certainly increase the number of foreigners visiting Indonesia. So that English becomes important as a medium of communication. In addition, tourism communities and students must be able to master and know about the local culture that is owned in their area. A mature insight into culture and fluent English will be very easy to introduce the richness of Indonesian culture and traditions to foreign tourists. As tourism students must be able to prepare their abilities in terms of insight into local culture and sharpen their English skills. With adequate English language skills, tourism academics and students will be greatly helped to develop tourism potential and local culture and be able to master other fields such as developing a creative economy and introducing tourism and Indonesian culture to other countries regionally and internationally to foreign tourists who come to Indonesia.

One of the keys to the success of the MEA is good relations between citizens and other ASEAN countries. Meanwhile, one of the most powerful media to build connectivity with ASEAN countries is through the mastery of a good foreign language, namely English. Mastering English means people can communicate with other people internationally and also by mastering English, they can learn many other fields such as tourism, art, technology, education, economics, culture, and politics. In this era of globalization, people who cannot communicate in English will take a step back from people who master English.

Table 1. Result of the Questionnaire

\begin{tabular}{|c|c|c|c|c|c|c|}
\hline Questionnaire Statement & Mean & $\begin{array}{l}\text { Std. } \\
\text { Dev }\end{array}$ & $\begin{array}{l}\text { Strongly } \\
\text { disagree }\end{array}$ & Disagree & Agree & $\begin{array}{l}\text { Strongly } \\
\text { agree }\end{array}$ \\
\hline $\begin{array}{l}\text { I can understand convergations in English without me having to } \\
\text { translate into Indonesian }\end{array}$ & 3.0909 & .81888 & $0 \%$ & $31.5 \%$ & $31.5 \%$ & $29.6 \%$ \\
\hline $\begin{array}{l}\text { I can listen words in English and understand the main idea of } \\
\text { the speech }\end{array}$ & 3.2182 & .82819 & $0 \%$ & $25.9 \%$ & $27.8 \%$ & $46.3 \%$ \\
\hline $\begin{array}{l}\text { I can understand when I listen the conversations in English in } \\
\text { long sentences }\end{array}$ & 2.6182 & 94802 & $0 \%$ & $53.7 \%$ & $22.2 \%$ & $24.1 \%$ \\
\hline $\begin{array}{l}\text { can tell the origin of someone's English accent by hearing the } \\
\text { pronunciation }\end{array}$ & 2.4182 & .89219 & $11.1 \%$ & $53.7 \%$ & $20.4 \%$ & $14.8 \%$ \\
\hline $\begin{array}{l}\text { I can respond to someone's words quickly and precisely in } \\
\text { Engligh }\end{array}$ & 2.8727 & .85787 & $1.9 \%$ & $38.9 \%$ & $29.6 \%$ & $29.7 \%$ \\
\hline I can speak in English clearly and correctly & 2.7636 & .89778 & $3.6 \%$ & $43.6 \%$ & $25.5 \%$ & $27.3 \%$ \\
\hline I can speak Engligh sentences that are quite long & 2.6545 & .96200 & $9.1 \%$ & $41.8 \%$ & $23.6 \%$ & $25.5 \%$ \\
\hline $\begin{array}{l}\text { I can explain information to customers so that he understands } \\
\text { in English }\end{array}$ & 2.7455 & .98088 & $9.1 \%$ & $36.4 \%$ & $25.5 \%$ & $29.1 \%$ \\
\hline I can read and know the main ideas of reading quickly & 2.5818 & .87138 & $5.5 \%$ & $50.9 \%$ & $23.6 \%$ & $20.0 \%$ \\
\hline I can understand reading a long article in English & 2.3818 & .90849 & $12.7 \%$ & $52.7 \%$ & $18.2 \%$ & $16.4 \%$ \\
\hline I can translate terms in English without using a dictionary & 2.5091 & .99305 & $12.7 \%$ & $47.3 \%$ & $16.4 \%$ & $23.6 \%$ \\
\hline $\begin{array}{l}\text { I can understand the context of a reading without having to } \\
\text { translate it with a dictionary }\end{array}$ & 2.5455 & .95434 & $10.9 \%$ & $45.5 \%$ & $21.8 \%$ & $21.8 \%$ \\
\hline I can dictate / record customer needs correctly & 2.7636 & .93776 & $7.3 \%$ & $36.4 \%$ & $29.1 \%$ & $27.3 \%$ \\
\hline I can write in Engliah with correct grammar & 2.8182 & .95957 & $5.5 \%$ & $40.0 \%$ & $21.8 \%$ & $32.7 \%$ \\
\hline I can write Formal English gentences & 2.6182 & .98597 & $10.9 \%$ & $41.8 \%$ & $21.8 \%$ & $25.5 \%$ \\
\hline $\begin{array}{l}\text { I can write using terms that are correct and in accordance with } \\
\text { the context. }\end{array}$ & 2.6727 & .93954 & $7.3 \%$ & $43.6 \%$ & $23.6 \%$ & $25.5 \%$ \\
\hline
\end{tabular}


People who master English will have modern thinking and they can learn a lot of studies to get a lot of innovation and a lot of experience and greater job opportunities than people who can't speak English.

Entering the AEC 2015 era requires that individuals, especially workers in the tourism sector, prepare prepared and competent resources. In this case, the role of English is needed both in communicating directly. The need for a paradigm change about the importance of English, which is a new perception that in the era of globalization in facing 2015. To prepare competent and capable human resources in English must be active and communicative to all elements of society that cannot be separated from the role of the government that issues policy and training programs to improve the ability of the community to speak English. Readiness of human resources is a major factor in the era of free markets.

According to Shobikah (2013), one of the main problems is English language skills which lead to a large gap between the quality of Indonesian skilled workers and workers from other Southeast Asian countries. In Indonesia, English is only studied but not used as an active means of communication in daily life. While in Southeast Asia, English is mainly as a lingua franca and is practically used daily. Southeast Asian countries see that Indonesia is the biggest market for workers. This means that Indonesian workers must be prepared for this competition in finding work and maintaining employment not fulfilled by workers from other countries. The study that concern about this have not been conducted, however the results of research in Bangkok, Thailand, as neighbor country of Indonesia can be used as the reflection, the study about workers from 26 tourism companies faced difficulties in English language skills in speaking and listening skills (Kuosuwan, 2016).

Thailand has opened Indonesian language courses massively throughout the country. This is done to send their workers and compete with local workers from Indonesia themselves. If Indonesian workers want to conquer other countries and defend their country, they must master the language. If they cannot communicate with other Southeast Asian languages, they can communicate in English as an international language. International means English is used in many countries in the world. For this reason, Indonesia must prepare its workers well through English education. The development of Indonesia's human resources can be built through many aspects, especially in the field of education. All preparations, from education to technology, are to prepare Indonesia's next generation especially tourism students to have readiness and become competent, skilled, professional human resources to be ready to compete with human resources from other ASEAN countries.

\section{RESEARCH METHOD}

This study aims to determine the level of readiness of English communication skills of 110 Tourism student respondents at the Mataram Tourism College. Because the number of samples is limited, random sampling is used. Data collection for this study was conducted through a questionnaire to obtain the opinions of respondents. According to Riduwan (2010), Data collection methods are techniques or ways that can be used by researchers to collect data. In this study, data collection methods used the Questionnaire Method. This 
questionnaire was used to collect data on student responses regarding the readiness of STP Mataram students in facing MEA. The questionnaire consists of 4 aspects of language skills, namely listening, speaking, reading and writing. The validity of each question in the questionnaire was carried out using the Item Objective Congruency or IOC index (Yamane, 1973). In addition, 10 respondents were selected as pilot studies to obtain the Cronbach Alpha Coefficient which can be received more than or equal to 0.75 .

\section{FINDING AND DISCUSSION}

From the results of the analysis it was found that among the 4 Language skills in the questionnaire, Mataram tourism students in general were still not ready in terms of communication skills using English. The result can be seen from the table 1 .

In general, from four of the Language skills, STP Mataram students are not capable or ready in communication skills using English, above 30\% the respondents answered that they have not been able or disagree. Based on the results of the table above, it was found that from listening skills, students of Mataram STP were not ready to understand long sentences or utterances of $53.7 \%$. In speaking skill, $43.6 \%$ have not been able to pronounce English sentences properly and correctly. In reading ability, students cannot understand a long article in English
(52\%), while in writing skills students have not been able to formally write sentences in correct English (41.8\%).

From the research findings, it is revealed that tourism students at STP Mataram need to develop and improve their skills in English communication, especially listening and speaking, which is a skill needed to communicate with foreign people. One of the reasons tourism students at STP Mataram are lack in this skill is because they are vocational students who focus more on the ability of tourism practice and have not focused on foreign language skills. Therefore, English language training must be provided by institutions or take courses in language centers to improve their ability to use English.

\section{CONCLUSION}

In order to develop human resources for tourism quality standards. The Mastery of English is one of the basic capital to be able to compete in the face of the globalization era, especially the ASEAN Community. In general, from the four skill of Language, STP students are not ready in using English as means of communication, above 30\%the respondents answered that they have not been able or disagree with the statement from the questionnaire. This finding reveals that tourism students at STP Mataramneed to develop and improve their skills in English communication,

Table 2. Result of Analysis of Each Item

\begin{tabular}{|c|c|c|c|c|c|c|c|c|c|c|}
\hline & & Respondent & $\begin{array}{l}\text { AUIC } 2 . \\
\text { Listen1 }\end{array}$ & Listen2 & $\begin{array}{l}\text { Listen } 3 \\
\text { List }\end{array}$ & $\begin{array}{r}\text { Listen } 4 \\
\text { List }\end{array}$ & Speaking 1 & $\begin{array}{l}11 \text { (Ctrl) } \\
\text { Speaking1 }\end{array}$ & Speaking1 & Speaking1 \\
\hline \multirow[t]{2}{*}{$\mathrm{N}$} & Valid & 110 & 110 & 110 & 110 & 110 & 110 & 110 & 110 & 110 \\
\hline & Missing & o & 0 & 0 & 0 & o & 0 & o & 0 & 0 \\
\hline Mean & & & 3.0909 & 3.2182 & 2.6182 & 2.4182 & 2.8727 & 2.7636 & 2.6545 & 2.7455 \\
\hline Median & & & 3.0000 & 3.0000 & 2.0000 & 2.0000 & 3.0000 & 3.0000 & 2.0000 & 3.0000 \\
\hline Std. Deviation & & & .81888 & .82819 & .94802 & .89219 & .85787 & .89778 & .96200 & .98088 \\
\hline Maximum & & & 4.00 & 4.00 & 4.00 & 4.00 & 4.00 & 4.00 & 4.00 & 4.00 \\
\hline
\end{tabular}

\begin{tabular}{|c|c|c|c|c|c|c|c|c|c|c|}
\hline & & Respondent & Reading1 & Reading2 & Reading 3 & Reading4 & Writing 1 & Writing 2 & Writing 3 & Writing 4 \\
\hline \multirow[t]{2}{*}{$\mathrm{N}$} & Valid & 110 & 110 & 110 & 110 & 110 & 110 & 110 & 110 & 110 \\
\hline & Missing & 0 & 0 & 0 & 0 & 0 & 0 & 0 & 0 & o \\
\hline Mean & & & 2.5818 & 2.3818 & 2.5091 & 2.5455 & 2.7636 & 2.8182 & 2.6182 & 2.6727 \\
\hline Median & & & 2.0000 & 2.0000 & 2.0000 & 2.0000 & 3.0000 & 3.0000 & 2.0000 & 2.0000 \\
\hline Std. Deviation & & & .87138 & .90849 & .99305 & .95434 & .93776 & .95957 & .98597 & .93954 \\
\hline Maximum & & & 4.00 & 4.00 & 4.00 & 4.00 & 4.00 & 4.00 & 4.00 & 4.00 \\
\hline
\end{tabular}


especially listening and speaking, which is a skill needed to communicate with tourist or foreign people. Therefore, English language training must be provided by institutions or take courses in language center to improve their competency to use English for communication.

\section{REFERENCES}

Kuosuwan, Bavornluck. (2016). The Readiness of English Communication Skills of Tourism Employees in Bangkok for Entering the ASEAN Community. International Journal Of Environmental \& Science Education 2016, Vol. 11, No. 18, 12903-12907.

Lewis, M. Paul (ed.). (2009). Ethnologue: Bahasa dunia . Dallas: SIL internasional Edisi keenam belas.

McCormick, C. (2015). English Proficiency Index (EPI). English First.

Riduwan. (2002). Skala Pengukuran Variabel-Variabel Penelitian. Bandung:Alfabeta.

Shobikah, Nanik. (2013). The Importance of English Language In Facing Asean Economic Community (AEC). At-Turats Vol. 11 No.1 (2017) 85 93. West Kalimantan.

Stiglitz, Joseph E. (2002). Globalization And Its Discontents. New York: W.W. Norton.

Ushakov, D. (2014). Government regulation of urban tourism system: Problems and limitations of efficiency (Case of Bangkok Metropolitan, Thailand). Actual Problems of Economics. \#6.

Wongleedee, K. (2012). Satisfaction, global senior tourist in Thailand. ICEMT Conference. 2012. (p.7-11). Suan Sunandha Rajabhat University.
Yamane, T. (1973). Statistics: An introductory analysis, 3rd edition, New York, Harper, and Row. 